Portland State University

PDXScholar

$5-24-2019$

\title{
Explaining the Collapse of the Industrial Workers of the World through Historiography
}

Kayla B. Gmyr

Portland State University

Follow this and additional works at: https://pdxscholar.library.pdx.edu/honorstheses

\section{Let us know how access to this document benefits you.}

\section{Recommended Citation}

Gmyr, Kayla B., "Explaining the Collapse of the Industrial Workers of the World through Historiography" (2019). University Honors Theses. Paper 738.

https://doi.org/10.15760/honors.755

This Thesis is brought to you for free and open access. It has been accepted for inclusion in University Honors Theses by an authorized administrator of PDXScholar. Please contact us if we can make this document more accessible: pdxscholar@pdx.edu. 
Explaining the Collapse of the Industrial Workers of the World through Historiography

by

Kayla Gmyr

An undergraduate honors thesis submitted in partial fulfilment of the requirements for the degree of

Bachelor of Science

in

University Honors

and

Social Science

Thesis Adviser

Dr. David A. Horowitz, Department of History

2019

Portland State University 


\begin{abstract}
Growing out of the labor militancy and political radicalism of the late nineteenth and early twentieth century, the revolutionary union Industrial Workers of the World (IWW) grew to be one of the most radical working-class movements in American history, containing 150,000 members during its peak in 1917. However, by its sixteenth convention in 1924, the union nearly collapsed beneath the weight of state repression, vigilante killings, organizational weaknesses, and political divisions, after which it remained on the fringes of labor politics. Many authors of varying backgrounds and decades have sought to explain the decline of the IWW, emphasizing either repression, internal organization, or political and programmatic questions as the fundamental cause. Through a historiographic review of scholarly and descriptive works, I argue for a more critical approach to the popularized focus on state repression, while highlighting the underrated value of organizational and political arguments. In doing so, I seek to strengthen not only the historical understanding of the IWW, but offer a fresh perspective on working-class politics, social movement history, and the American history in which the IWW is a part.
\end{abstract}




\section{Introduction}

Given the relatively low levels of strike activity in the past few decades, one might be surprised to learn of the militancy that characterized working-class struggles in the late nineteenth and early twentieth centuries. This was a period in which the industrial working class grew in size amid the flourishing of American capitalism, the rise of overseas imperialism, world war, and demographic shifts rooted in a large influx of immigrants, Mexican-Americans, and Southern blacks migrating to northern and midwestern cities. Hundreds of thousands of factory workers, miners, longshoremen and other workers of diverse skill levels risked their jobs and sometimes lives to strike, rally, and demonstrate against companies and government administrations in the interests of decent working and living conditions.

In 1905, the Industrial Workers of the World (IWW) arose as an organized revolutionary labor movement, building upon the prior years of workplace militancy and radical politics that characterized the Western Federation of Miners (WFM), American Labor Union, and Socialist Party. The IWW grew into a large-scale labor and social movement, with up to 150,000 members or "Wobblies" by 1917 , with the most radical program of any mass labor organization in American history. "Between these two classes [the working class and capitalist class]," the militants stated in the preamble to their 1905 constitution, "a struggle must go on until all the toilers come together on the political, as well as on the industrial field, and take and hold that which they produce by their labor, through an economic organization of the working class ${ }^{1}$ without affiliation with any political party." ${ }^{2}$ Advancing an American-style syndicalism, the

\footnotetext{
${ }^{1}$ According to the IWW definition, which aligns with Marxist economic theory, the "working class" is a social group that is bound in "wage slavery", forced to sell its labor to employers for a wage, while the "employing class" acquires profits and wealth. The divisions between the working class by trade, region, nation, gender, and ethnicity are seen by the IWW as arbitrary, enforced by the employing class for repressive purposes.

${ }^{2}$ Industrial Workers of the World, “The Original I.W.W. Preamble," General Website (2018).
} 
Wobblies refused to sign negotiated contracts, opting instead for militant direct action to sabotage both the public-sector and private bosses. Even with the financial difficulties, political disagreements, state repression, and interpersonal conflicts present throughout the organization's life, the IWW successfully organized workers in specific industries, such as timber, mining, agriculture, and shipping ports, mostly in the Western region of the United States where free-spirited migratory and immigrant workers made up the majority of the labor force.

However, the organization underwent a transition after its mountainous peak in 1917 , when its successes did not last. Facing a number of difficulties associated with the changing post-war economy, ramped up state repression during the Palmer Raids and First Red Scare, and various internal political and organizational conflicts, the Wobblies came under immense pressure. By the time of their Fifteenth Annual Convention in the summer of 1924, the "One Big Union" had become fragmented, divided, and lacked the tried and true leaders of the former period. The convention proved to be a turning point, marking the collapse of the once-massive organization into a small group of "old guard" radicals who existed on the fringes of mainstream left-wing politics and industrial trade unionism. While the organization exists today, and has actually grown in the past two years through small-scale unionization efforts in the Pacific Northwest, ${ }^{3}$ new members relate to the early struggles only through historical archives. Today's Wobblies focus more on ecological and anarchistic activism and local unionism than the industry-wide revolutionary syndicalism of the movement's founding.

The rapid collapse of such a large and significant movement in American social history strikes my interest. A wealth of historical material exists on the booming period of the IWW

\footnotetext{
${ }^{3}$ After largely failed unionization efforts in the past decade, the Wobblies launched the Burgerville Workers Union in 2018 and Little Big Union in 2019 in Portland, Oregon, with other success across the food and service industries. For an overview, see Teke Wiggins, "The Food Industry Has Been Notoriously Hard to Organize," Huffington Post (October 9, 2018).
} 
between its founding in 1905 and defense campaigns in $1919 .{ }^{4}$ In contrast, the drastic decline of the mass revolutionary workers' organization has received scant attention. The relative lack of engagement with the collapse of the movement reflects an understandable intrigue with the positive and romantic side of radical politics, perhaps especially so since most IWW historians are either sympathetic to the organization or to social movements in general. Of the histories and analyses of the IWW's decline that do exist, the notable works are separated from one another over nearly a hundred years, scattered in a handful of comprehensive works, ${ }^{5}$ brief chapters of larger works that cover either the IWW's activities before $1917^{6}$ or include the IWW as part of broader themes on social movements, ${ }^{7}$ and political essays by left-wing activists. ${ }^{8}$

Authors have explained the decline of the IWW as a product of interacting factors. These include the jailing or murder of its leadership by company security forces and government agents, state censorship and raids, the impact of the Bolshevik Revolution and growth of the Communist Party, the strengthening of other less-radical forms of trade unionism, organizational weakness, financial difficulties, and broader changes in the global post-war economy that led to the stagnation of wages and working conditions. Because of the long periods separating existing scholarship, along with the wide assortment of authors involved, there does not yet exist a comprehensive review of the IWW's decline. Further, the popularized narrative that the

\footnotetext{
${ }^{4}$ Notable sources include John Graham Brooks, American Syndicalism: The IWW (New York: The Macmillan Company, 1913); Paul Brissenden, The IWW: A study of American syndicalism (Russel \& Russel, 1920); Melvyn Dubofsky, We Shall Be All: A History of the Industrial Workers of the World (University of Illinois Press, 1993); James Gregory \& Conor Casey, The IWW History Project (University of Washington, 2019); Robert L. Tyler, Rebels of the Woods: The IWW in the Pacific Northwest (Oregon State University Press, 1967); Fred Thompson \& Patrick Murfin, The IWW, Its First Seventy Years, 1905-1975 (Chicago: Industrial Workers of the World, 1978).

${ }^{5}$ John Gambs, The Decline of the I.W.W. (Columbia University Press, 1932); Leland Robinson, Social Movement Organizations in Decline: A Case Study of the IWW (Northeastern University, 1973).

${ }^{6}$ Dubofsky, We Shall Be All, 461-66.

${ }^{7}$ Robert Goldberg, "One Big Union: The Industrial Workers of the World," Grassroots Resistance: Socialist Movements in the 20th Century (1990); Kenyon Zimmer, "Premature anti-communists? American Anarchism, the Russian Revolution, and Left-Wing Libertarian Anti-Communism, 1917-1939," Labor: Studies in Working-Class History of the Americas (2009).

${ }^{8}$ Cannon, James P. "The I.W.W.," Fourth International (1955).
} 
movement's collapse is rooted primarily in state repression contradicts the majority of historical contributions that portray repression as a pressure, which merely exacerbated more fundamental internal organizational or programmatic tensions.

I aim to provide an integrated explanation of the Wobblies collapse through the methods of historiography, with which I bring distanced historical works into communication with each other, account for the different explanations of the IWW's decline with regards to the backgrounds of authors and the respective eras in which they worked, and suggest new conclusions on the subject that arise from their findings. Through a historical review of scholarly and descriptive works across decades and varying perspectives, I argue for a more critical approach to the popularized explanation of state repression as the fundamental factor in the decline of the IWW after 1917. In doing so, I seek to strengthen the historical understanding of the IWW, which may lend a fresh perspective to broader fields of working-class politics and social movement history.

The first section of this thesis essay provides the historical background to the key events and broader context in which the decline of the IWW developed. It includes descriptive material that repeatedly appears in the secondary works under historiographic analysis. The essay then proceeds to summarize how the ten authors explain why these events took place, organizing this material into three groups by the fundamental reason each sees behind the decline. Based on these categories, the second section examines works emphasizing state and cultural repression, the third section includes works that focus on internal organizational weaknesses, and the fourth section explores works that stress the programmatic questions that related to communism, anarchism and trade unionism. Additionally, this section examines what seem to be the motivating factors behind the author's narratives. A final segment offers suggestions on 
the implications of the historiographic analysis, and what it may mean for the way we understand the decline of the IWW and social movements more broadly.

\section{Historical Context and Wobbly Life}

After years of geopolitical tensions and economic instability, the First World War officially started on July 28,1914 . That date marked a turning point in world history, producing mass casualties and social instability that galvanized political radicalism, labor struggles, and movement-building of wide layers of the working class and exploited people around the world. In the midst of the war-time period, the revolutionary waves that swept across much of Europe found expression in the United States as well. ${ }^{9}$ Elements of the American working class launched rebellions of its own, organized in unions and left-wing parties that had been growing since the late nineteenth century. Notable strikes include those by five thousand copper miners in Arizona in January 1916, sixteen thousand steelworkers in Youngstown, Ohio in 1915, thousands of Standard Oil workers in New Jersey in both 1915 and 1916, and New York City transit workers in 1916. Corresponding with the rise of large-scale strikes, the two decades following the turn of the century witnessed a surge in progressive, radical and anti-war politics. The Socialist Party, which was formed in 1901 and overlapped slightly with Wobbly membership, expanded its influence through unions and elections, obtaining over 900,000 votes for famed candidate Eugene Debs in 1912 and 1920.

\footnotetext{
${ }^{9}$ For further reading on labor militancy, radical politics and anti-war movements in the early twentieth century, see Philip Foner, "Labor and World War I, 1914-1918," History of the Labor Movement in the United States, Vol. 7 (International Publishers, 1987); Jack Ross, The Socialist Party of America: A Complete History (Dulles: Potomac Books, 2015), 58-236; Michael Kazin, War Against War: The American Fight for Peace, 1914-1918 (Simon and Schuster, 2017); Neil Hamilton, Rebels and Renegades: A Chronology of Social and Political Dissent in the United States (Routledge, 2002), 133-198; Palmer, Bryan D. Palmer, James P. Cannon and the origins of the American revolutionary left, 1890-1928, (University of Illinois Press, 2007).
} 
In the first two decades of the twentieth century, a period of progressive politics and labor militancy in the United States and internationally, the Industrial Workers of the World (IWW) stood out as the most radical of the mass labor organizations to which many workers committed themselves. ${ }^{10}$ One of the largest unions at the time was the American Federation of Labor (AFL), which grew under the presidency of Samuel Gompers from 50,000 members in 1886 to around 3 million in $1924 .{ }^{11}$ Unlike the AFL, which leveraged relations with the state and compromised with big business to win major concessions, ${ }^{12}$ the IWW relentlessly opposed World War One as an imperialist venture along with the left-wing of the Socialist Party and the anti-war coalition. Whereas the AFL prohibited minority workers, women and unskilled workers from organizing alongside with their counterparts, the IWW sought to unify workers across divisions of gender, race, nationality and occupation in militant struggles for improvements in working and living conditions that did not accept friendly compromise with the bosses. The tensions between the radical and conservative unions sharpened in 1914 to such a degree that the AFL unofficially coordinated with the U.S. establishment to support the war effort and help "crush radical labor groups" like the IWW and Socialist Party. ${ }^{13}$

Though the IWW never achieved the million-strong unions of the AFL, membership in its “One Big Union" peaked at more than 150,000 in $1917 .{ }^{14}$ Labor militancy during World War One culminated in general strikes along the West Coast and other major port cities by 1919, including the Seattle General Strike in early February. Miners, longshoremen, lumber workers and agricultural workers were among the most radical sectors of the working class, in part due

\footnotetext{
${ }^{10}$ Though most widely known as a distinctly American working-class and political movement, the Wobblies were active in other countries, such as Britain, Australia and South Africa. See Peter Cole, Wobblies of the World: A Global History of the IWW (London: Pluto Press, 2017).

${ }^{11}$ AFL-CIO. "Samuel Gompers", Key People in Labor History (2019).

${ }^{12}$ Concessions won through Gompers' pragmatic strategy included better wages, an eight-hour work day, equal pay for women, a role on wartime government commissions, and collective bargaining rights.

${ }^{13}$ Robert J. Goldstein, Political Repression in Modern America: From 1870 to the Present (Cambridge, 1978), 121.

${ }^{14}$ Goldberg, "One Big Union,” 62.
} 
to their isolated, ethnically-diverse, and migratory position in society. Thus, these segments composed the bulk of active IWW locals. Through its largest labor actions in Arizona, Chicago, and Oregon, as well as its famous free speech fights in California, Montana, and Washington state, the Wobblies garnered a reputation for its militant workplace efforts and distinct cultural artifacts. ${ }^{15}$ Many of its founders and leading members became recognized as icons in organized labor and left-wing politics, including Eugene Debs, William "Big Bill" Haywood, Daniel DeLeon, Vincent St. John, Lucy Parsons, Mary "Mother" Jones, James Connelly, Thomas Hagerty, Joe Hill, John Reed, James P. Cannon, and Frank Little.

In popular accounts, the first twelve years of the IWW are often romanticized as a period of linear growth in strength, numbers, and successes. However, the organization faced a great deal of conflict from within and outside its ranks. During the founding convention in 1905, members engaged in heated discussion over the programmatic foundations upon which the IWW would be built, drawing lines that would persist over the course of their lives. During high and low points, the Wobblies were divided in the camps of Marxian and reformist socialists, anarchists, and conservative unionists and industrial militants. "They all believed in the 'irrepressible conflict' between capital and labor. They were a unit in wishing for and aiming at the overthrow of the wages system--the downfall of capitalism," wrote Paul Brissenden in The IWW: A Study of American Syndicalism, but, "as usual, there was disagreement as to the methods to be used to reach the common end desired." ${ }^{\text {16 }}$ These disagreements at times led to intense debates, the expulsion of members, and the shutting down of some locals, projects, and publications.

\footnotetext{
${ }^{15}$ Wobblies have historically been known for their songs and parodies of religious hymns, around which members formed bonding rituals. See a modern expansion of the original "Little Red Songbook" in Archie Green, The Big Red Songbook: 250 IWW Songs! (C.H. Kerr Company, 2016).

${ }^{16}$ Brissenden, The IWW, 77.
} 
However many issues existed internally, government officials and business interests viewed the IWW as a potential threat to wartime industrial mobilization. Indeed, the movement faced severe repression by government bodies, police, the courts, major newspapers, and religious institutions. The work of Foner and Dubofsky in particular reveal how capitalist interests utilized the IWW, as well as other historically militant unions like the WFM, as a scapegoat to hide worsening social tensions between capital and labor. Rarely did the IWW unionize the majority of workers within an industry or city, but their tactics and views of the world resonated deeply with workers, in a way that arguably encouraged the use of industrial solidarity and militant direct action. This form of working-class resistance posed a threat to the profit interests of the companies and nation-state interests pursued by the United States in World War One, as the Wobblies sought to sabotage the war effort with strikes in logging and shipyard industries that were critical to military operations. At times, the government exhibited wartime paranoia and xenophobia, accusing the Wobblies of being agents of the German government or as Bolshevik revolutionaries aiming to violently destroy the foundations of American society.

Facing anti-union and anti-radical repression since its inception, the Wobblies suffered from stepped up state attacks during WWI that included arrests, imprisonment, murder, censorship of publications, criminalization of activity and membership, and raids on their physical centers. The federal Espionage Act of 1917 and Sedition Act of 1918 legally embodied state repression of political and union activity. By 1919, Wobbly leaders such as William "Big Bill" Haywood, Vincent St. John, James P. Cannon, Elizabeth Gurley Flynn, and Frank Little had been imprisoned by police or murdered by vigilante action. In addition, hundreds were targeted during and immediately after World War One. Agents of the Bureau of Investigation ${ }^{17}$ raided every IWW office in the country on September 5, 1917. In 1918, the government charged over

\footnotetext{
${ }^{17}$ Predecessor of the Federal Bureau of Investigation (FBI).
} 
one hundred members with over 10,000 violations of federal law in the Chicago Wobbly Mass Trial. ${ }^{18}$ Many major acts of repression occurred outside an official legal framework, as in the Centralia Tragedy of 1919, during which six people died and many more were injured or arrested after a standoff between American Legion vigilantes and Wobblies at an Armistice Day parade in 1919. During this period, many of those locked away or dead due to repression were essential to the day-to-day operations of the organization, as well as leading the membership with inspirational energy. Having lost its most significant and active members, large quantities of literature and material assets, and dues from increased competition by company unions after the war, the organization came under immense pressure. In the years that followed 1917, the remaining members focused on defense campaigns to raise funds to bail out the "class war prisoners" and rebuild the financially-weak organization.

Aggregating after an abnormal break in national meetings, the IWW nearly collapsed at the 1924 convention. The organization confronted two immediate sparks that set off the mortal flames. The first was the tension between sections of the movement, which reached new levels between 1922 and 1923 regarding how certain locals responded to new events. After years of defense campaigns that resulted in minimal successes, newly-elected President Warren Harding commuted the sentences of eleven Wobblies in December 1922 on the condition they withdrew their union membership. He subsequently offered to commute the sentences of most remaining prisoners if they agreed to "remain law-abiding and in no way to encourage law-breaking."19 Those who had accepted the offer were rejected by the bulk of the membership and remaining prisoners, whose sentences were commuted by President Calvin Coolidge in December 1923 under terms deemed more principled. Criticism of the handling of the

\footnotetext{
${ }^{18}$ Steven Parfitt, "The Justice Department Campaign Against the IWW, 1917-1920", The IWW History Project (University of Washington, 2015).

${ }^{19}$ Dubofsky, We Shall Be All, 263.
} 
commutation stemmed from the Harding's characterization of the union's "law-breaking" ways, when the IWW loyalists historically defended their basic democratic and legal rights as a political-labor organization. After these events, the majority of members carried a distrust of significant leaders, such as Ralph Chaplin, and led bitter factional arguments within their publications and internal meetings.

This major organizational controversy was soon accompanied by a second, regarding the mandatory dues increases issued by a Philadelphia local. Technically, the decision of local leadership violated the constitutional limits on dues, but the local leaders continuously justified the increases by citing higher operation costs. Though the events focused on questions of strategy and finances, disaffected members took these issues to represent a centralist, bureaucratic trajectory within the executive leadership that conflicted with anarchistic tenets.

Thirdly, the IWW confronted heavy political pressure by the Communist International (Comintern) after the Bolshevik Revolution in 1917. In January 1920, the Executive Committee of the Comintern issued a letter to the IWW, inviting them to join the international communist movement's labor wing, the Red International of Labor Unions. "We address this letter to you, fellow-workers of the I.W.W., in recognition of your long and heroic service in the class war, of which you have borne the brunt in your own country, so that you may clearly understand our Communist principles and programme. We appeal to you," the Executive Committee introduced, "as revolutionists, to rally to the Communist Internationale, born in the dawn of the World Social Revolution." ${ }^{20}$ While the letter sought to directly address the long-standing concerns held by IWW members of the authoritarian, bureaucratic potential of the Bolsheviks, it prompted a division within the Wobblies over how to respond. Amid the heated debates at annual leadership and membership events, George Williams waged a vocal campaign against the Comintern,

\footnotetext{
${ }^{20}$ Central Executive Committee of the Communist International, "To the I.W.W., A Special Message from the Communist International," (1920).
} 
arguing, as Dubofsky writes, that "a communist takeover would leave the Wobblies with neither an organization nor principles." ${ }^{21}$ In the end, the IWW general executive board took to the argument and voted against entry into the Comintern's labor wing in 1922. "The history of American unionism testifies to the destructive influence of labor politics and politicians," the leaders wrote to justify their decision. ${ }^{22}$

These two sets of problems at the 1924 convention embroiled delegates over both the political and organizational disagreements. ${ }^{23}$ To aggravate matters, two disputing factions of union leadership had scheduled two separate sessions for members to choose between. The first consisted of the long-standing elected leadership, represented by Tom Doyle and Joe Fisher; and the second was comprised of anti-leadership members led by James Rowan and M. Raddock. On the fifth day of separate meetings, bitter conflicts, and suggestions for breaking up the organization, delegates voted to suspend the IWW's entire national leadership, including most of the general executive board and the Lumber Workers' union, the IWW's largest affiliate. After legal battles over which faction would control of the union's declining assets and dwindling membership, the Rowan faction became the official IWW, drafting its own "Emergency Program". ${ }^{24}$ Long-time leaders like Richard Brazier and Forrest Edwards drifted away, as did the majority of the membership. As business unions, some AFL sections, and the Communist Party fared much better in the 1920s than the IWW, most members did not feel compelled to commit themselves to saving either faction within their own movement and, in the words of Fred Thompson, "dropped out the middle."

\footnotetext{
${ }^{21}$ Dubofsky, We Shall Be All, 264.

${ }^{22}$ Ibid. For the minority pro-Soviet view, see Harrison George, The Red Dawn: The Bolsheviki and the IWW (Chicago: I.W.W. Publishing Bureau, 1918).

${ }^{23}$ Dubofsky, We Shall Be All, 263-5.

24 John Gambs, The Decline of the I.W.W., 100.

${ }^{25}$ Fred Thompson and Patrick Murfin, The IWW, 151.
} 
Scholars generally agree upon the 1924 convention as the final turning point, the marker of collapse after years of degeneration. Rowan's official continuation of the IWW struggled to keep members and locals around, as many flocked to either mainstream unions or more defined political tendencies, like communism or anarchism. Many of its own members and leaders, such as James P. Cannon, had joined the Communist movement as it attracted rising numbers of radical workers after the 1917 Bolshevik Revolution, albeit with its own rocky start full of splits and divisions. ${ }^{26}$ While the IWW led the Colorado Miners Strike in 1927, among other working class struggles in the Twenties, ${ }^{27}$ the movement fell into the fringes of labor activity and progressive politics. During the 1930s, other industrial unions, the largest being the Congress of Industrial Organizations ( $\mathrm{ClO})$, prospered amid the Great Depression and gained support from Franklin D. Roosevelt's New Deal policies. ${ }^{28}$ By the start of the Second World War in 1939, the IWW had dwindled to little more than a small union scattered in a handful of cities.

The IWW maintained its organization with what was left of the old and demoralized leadership, issuing statements against capitalism, fascism, and Communism. ${ }^{29}$ Today, they operate in small-scale unions mostly in the Pacific Northwest, focusing on occasionally-successful local efforts to organize the service industry, participate in anti-fascist demonstrations, and promote environmental politics. After years of failed attempts to unionize fast food restaurants and small businesses, the Wobblies have grown their membership through fast-food unions at Burgerville and Little Big Burger in Oregon, with their largest national branch in Seattle, Washington. The Burgerville Workers Union is the first fast-food union recognized by

\footnotetext{
${ }^{26}$ Fraser Ottanelli, The Communist Party of the United States: From the Depression to WWII (Rutgers University Press, 1991), 9.

${ }^{27}$ For accounts of IWW activity in the 1920s, see Charles Bayard, "The 1927-1928 Colorado Coal Strike," Pacific Historical Review, Vol. 32, No. 3. (1963); Robert E. Ficken, "The Wobbly Horrors: Pacific Northwest Lumbermen and the Industrial Workers of the World, 1917-1928," Labor History (1983), 325-41; Fred Thompson and Patrick Murfin, The IWW.

${ }^{28}$ For one example of how industrial unionism spread beyond the IWW, see Lizabeth Cohen, Making a New Deal: Industrial Workers in Chicago, 1919-1939 (Cambridge University Press, 1990).

${ }^{29}$ Dubofsky, We Shall Be All, 464.
} 
the National Labor Relations Board (NLRB), and thus has the ability to negotiate contracts with employers and other traits of mainstream unions. While retaining the logo, red cards, and historical documents of 1905, the Wobblies of today are too anarchistic, parochial, and "pure and simple" unionist in character to be considered a direct extension of their century-old founders.

\section{Perspectives on State Repression: The Pessimistic Minority}

For an organization to transform so drastically, its story is bound to be complex, protracted, and full. The IWW endured many experiences between its peak in 1917 and its latest adventures today, over the course of decades in which the world around it changed as well. Contrary to the complexity that should be expected, the popular official histories paint a straightforward picture. According to these narratives, it arose from radical ashes and carried out impressive work with brave leaders, but unfortunately, the repressive forces of the state and corporations achieved their aims of smothering the movement into practical non-existence, set aside the past two years. State repression lay at the heart of the majority of histories that one finds in popular texts, such as brief summaries, online resources and at the conclusion of favorable writings on the Wobblies' heyday. The following excerpts from online encyclopedias and major texts on the IWW highlight this dominant explanation:

- Federal and state governments moved to suppress the organization, imprisoning hundreds of Wobblies, passing criminal syndicalism laws that made membership a crime. The IWW survived and is active today, but never regained the momentum of its early years. ${ }^{30}$

- The region's logging then came under the control of the U.S. Army... Wartime sedition laws and their enforcement by the FBI, Military Intelligence, and police 'red

\footnotetext{
${ }^{30}$ Gregory, James and Conor Casey, The IWW History Project (University of Washington, 2019) Web.
} 
squads' also left the IWW much diminished. The IWW never recovered and Communist groups eclipsed it after the war. ${ }^{31}$

- In the postwar years, the IWW underwent further scrutiny and prosecution by local officials responding to widespread antiradical sentiments. By 1925 membership in the IWW had dwindled to insignificance. ${ }^{32}$

While not a single figure denies the significance of state repression on the IWW, this group of authors places it at the forefront. They are also joined by modern historians who study political repression and the IWW generally, as well as former Wobblies who have reflected on the decline. Though these narratives have all been published since the late 1970s and are the minority in numerical terms of works produced on the topic, their arguments occupy the dominant position in popular media where the public will most readily find information regarding the movement, especially online.

A brief review of key scholars within this group may help to understand the origins and implications of the emphasis on repression. Adam Hodges, who wrote in the Oregon Encyclopedia entry (2018) that business and state repression "left the IWW much diminished," sits among the youngest modern historians writing on the topic. Currently an Associate Professor in the Human Sciences and History Department at the University of Houston, Hodges writes on U.S. labor history of the twentieth century, often examining methods of political suppression against the working class during World War One and the Red Scare. ${ }^{33}$ Though his analysis of the decline of the IWW does not extend beyond the encyclopedia entry, he articulates the common features of his colleagues in a concise way, revealing how his views

\footnotetext{
${ }^{31}$ Adam Hodges, "The Industrial Workers of the World," Oregon Encyclopedia (2018).

${ }^{32}$ Kathleen Scheetz, "Industrial Workers of the World," Encyclopedia Britannica (2019).

${ }^{33}$ Other works of Adam J. Hodges include The Industrial Workers of the World and the Oregon Packing Company Strike of July 1913, Master's Thesis (Portland State University, Dept. of History, 1996); "Thinking Globally, Acting Locally: The Portland Soviet and the Emergence of American Communism, 1918-1920," Pacific Northwest Quarterly, Vol. 98, No. 3 (2007); World War I and Urban Order: The Local Class Politics of National Mobilization (Palgrave Macmillan, 2016).
} 
may be shaped by the context in which he focuses on the impacts of repression on American labor.

Robert Goldstein is one of the leading historians within the field of political repression in the United States and Europe, and has applied this research to the IWW. As a former professor at the University of Michigan and Oakland University, Goldstein has written numerous texts on censorship, repression, and violence by the state against political groups and labor organizations. ${ }^{34}$ In one of his well-known books, Political Repression in Modern America: From 1870 to the Present (1978), he accounts for the various ways in which the U.S. government sought to crush radical movements, often violating basic legal and democratic rights. The impacts of these state efforts on labor organizations were deadly, he argues, and the Wobblies were irreparably damaged by the violence waged against them. "The attack of the federal and local governments, along with those of vigilantes," Goldstein states, "totally disrupted the IWW leadership, dispersed its membership, and destroyed IWW locals." ${ }^{35}$ Repeatedly emphasizing that its local unions were obliterated as a direct consequence of the state's repressive mechanisms, he presents the view that the Wobblies did their best but were no match for the powerful government forces that wanted them dead. Goldstein is not an expert on the general history of the Wobblies, but his work appears vital to understanding the basic assumptions and conclusions that IWW historians employed in similar analyses of the decline.

Several non-academic authors worked to compile an oral history anthology, titled Solidarity Forever (1985), which is recognized as a helpful collection of first-hand accounts by former Wobblies. Edited by the radical writers and artists Dan Georgakas, Steven Bird, and

\footnotetext{
${ }^{34}$ Major works include Little "Red Scares": Anti-communism and Political Repression in the United States, 1921-1946, (Ashgate, 2014); American Blacklist: The Attorney General's List of Subversive Organizations (University Press of Kansas, 2008); Burning the Flag: The Great 1989-1990 American Flag Desecration Controversy (Kent State University Press, 1996).

${ }^{35}$ Goldstein, Political Repression in Modern America, 132.
} 
Deborah Shaffer, the collections provide a look into how the emphasis on state repression developed in the thought of members as they dealt with its daily consequences. The authors devote an entire chapter to "Continued Repression and Decline", in which former members recount how they grappled with changing conditions before and after $1924 .{ }^{36}$ While the stories of former Wobblies vary in their interpretations of the causes of the collapse, often including organizational and political matters, there is a strong grounding of their stories in the arrests and raids that many of them endured first hand. "We still had IWW members conducting strikes, but the movement made from 1910 to 1920 had been destroyed," Nicolaas Steelink recounted, "We didn't have enough workers to carry on... Each time we seemed about to go ahead, another wave of repression hit us. We just declined." ${ }^{37}$

Some historians extend the category of state repression to include cultural backlash of middle-class elements and hostile attitudes of the media and politicians, which aimed to alienate the Wobblies from public acceptance. John Townsend carried out the most thorough work of this cultural perspective, though he is not the only scholar to do so. ${ }^{38}$ With little information known about his personal or educational background, Townsend is well-known among the IWW historical community for his collection of media opposing the movement throughout its life in Running the Gauntlet: Cultural Sources of Violence against the IWW (1986). ${ }^{39}$ Drawing upon newspapers, political speeches, official statements and correspondence, Townsend examines how general fears within the public created the environment for violent state repression to proceed without mass opposition. He specifically looks at the reactions of three key layers of

\footnotetext{
${ }^{36}$ Bird, et. al., Solidarity Forever (Chicago: Lakeview Press, 1985), 191-202.

${ }^{37}$ Ibid., 201-202.

${ }^{38}$ A number of the major historical works on the IWW listed elsewhere in this thesis include the "cultural conflict" that emerged between middle-class American values and the Wobblies' socially progressive culture. Few works explore the topic alone, including Andrew Bryans, "The response to left-wing radicalism in Portland, Oregon (1917-1941)," PDXScholar (Portland State University History Department, 2002).

39 John Townsend, Running the Gauntlet: Cultural Sources of Violence against the IWW, (New York: American Legal and Constitutional History, 1986).
} 
affluent American society--big business with their defense of profitability, the middle class with their commitment to American social values, and the U.S. government with their fear of strikes, progressive movements and revolution. "Wartime hysteria," Townsend asserts, "traded on by a government anxious to mobilize the country for the war effort, ensured the destruction of the IWW" in a process that only intensified following the conclusion of the war. ${ }^{40}$ According to this perspective, the fears within upper strata of society laid the basis for the official description of the IWW as a band of violent agitators out to destroy America, lending justification to repressive measures that crushed it. Further, Townsend explains that the explicit defense of the United States in wartime was joined by conservative opposition to the Wobblies' birth control advocacy, "free love", ethnic pluralism, and other socially liberal issues. The IWW could easily be turned into a scapegoat by sections of the privileged classes, who saw in their radical unionism the antithesis of all the ethical, economic and social norms of American capitalism.

The work carried out by this group of scholars offers valuable contributions to the history of the IWW by documenting political repression carried out by the United States government. However, there are limitations and implications in these works which must be explored. First, many of these works offer only a brief examination of the decline period, either adding a quick conclusion at the end of a long pre-1917 historical piece, or including the IWW within a broader analysis of state repression. Second, given that all of the authors wrote these texts in the last fifty years, they formed their arguments as the activity, organizations, and social conditions of the working class were suppressed. Without being conscious of the period in which they carried out their research, they may have been influenced by the emergence of conservative economic policy, anti-union fervor, and declining levels of strike activity that began in the late 1970s, which created the appearance of the victory of the capitalist state over the working class. Third, these

\footnotetext{
40 Townsend, Running the Gauntlet, 214.
} 
authors focus almost exclusively on the oppressive factors external to the organization, implying that the internal conditions were subordinate to those factors and out of members' control. The logical conclusion of such a focus is that the fate of the IWW--or any political or labor movement for that matter--rests in the hands of those in power, and there is hardly a strategy to overcome the inevitable crackdown pursued by a fearful state. Is such a pessimistic, fatalistic proposition valid? If so, what is the point of a radical movement from below? If not, what could the IWW membership have done to avoid its collapse? What could be said of organizations in the U.S. and internationally that have survived state repression? While all historians agree that the repression carried out by the U.S. government placed a huge burden on the organization, the majority seem to consider it a heavy pressure that exacerbated, but did not fundamentally cause, the rifts that tore the organization apart.

\section{Perspectives on Organizational Weaknesses: The Pessimistic Majority}

Of all the histories produced regarding the Wobblies in decline, those that emphasized the internal organizational failures were among the first and most highly regarded works. John Gambs, a young scholar at Columbia University intrigued with radical social movements, took the first attempt at accounting for the IWW's collapse with a dissertation titled The Decline of the IWW (1932) ${ }^{41}$ His work laid the foundation for many preceding endeavors, with his name cited in every significant reflection on the decline. In the socially radical period of the late 1960 s and early 1970s, Leland Robinson and Melvyn Dubofsky reworked Gambs' general perspective with a wealth of new material. Robinson wrote the only other comprehensive work on the decline, Social Movement Organizations in Decline: A Case Study of the IWW (1973), ${ }^{42}$ and Dubofsky produced one of the most authoritative books on the IWW, We Shall Be All: A History of the

\footnotetext{
${ }^{41}$ Gambs, The Decline of the I.W.W.

${ }^{42}$ Robinson, Social Movement Organizations in Decline.
} 
Industrial Workers of the World $(1967,1993)$, with two chapters devoted to its decline. ${ }^{43}$ These writers do not offer a detailed assessment of political perspectives in flux, or their relationship to a changing external environment. Rather, they show how political tensions impacted the day-to-day work of the movement, through the lens of individual actors, social and financial pressures, and strategic planning issues. By looking at these internal controversies, the authors seek to find connections between the trajectory of the IWW with social movements and political organizations in general.

The dissertation produced by John Gambs was the first comprehensive assessment of the IWW after it had collapsed, openly intended to be a continuation of an earlier overview by Paul Brissenden. ${ }^{44}$ Carrying out historical work with a generalized interest in politics and revolution, Gambs acknowledges that his engagement with the IWW is contingent on whether it "throws light on social change." ${ }^{45}$ He mostly focused on the period between 1917 and 1924, during which the basic splits of leadership occurred, aiming to surface these post-1917 events in a comprehensive form for the first time while reviewing their implications for the following years. Included in the dissertation are vast quantities of primary material on public opinion, the response of the IWW to repression, the internationalism promoted by the Communist movement, the 1924 convention, union struggles in the 1920s, education and organization, and the American labor movement as a whole. Thus, the text serves a greater function as a collection of primary documents and research, rather than as a thorough analysis of the forces driving events. Due to the constraints of a historiographical focus, I am not able to incorporate the majority of his research into my analysis. However, the insights are significant in that they constitute the first official historical narrative about the collapse independent of the IWW.

\footnotetext{
${ }^{43}$ Dubofsky, We Shall Be All.

${ }^{44}$ Brissenden, The IWW.

${ }^{45}$ Gambs, The Decline of the IWW, 5.
} 
Although pointing to the importance of state repression, strategic debate, and difficulties as a union, he concludes that the fundamental factor at work was the movement's lack of flexibility to adapt to changing conditions:

The I.W.W. need not grow in size to be heard from again; it does not need to engage in spectacular activities. It must, however, have able leaders and intelligent members. These it lacks today... One of the prime tests of intelligence is the ability to grow and develop; to meet the problems of a changing environment. The I.W.W. is willing to change the world, but it is not willing to change itself. Members with constructive suggestions for change and adaptation to post-war conditions are not encouraged to express their opinions. Inflexible, dogmatic, fatalistic--that is the I.W.W. today. ${ }^{46}$

Thus, leaders and members, the living organizational components, were at the heart of the IWW's failure to develop its strength and perspectives in the tumultuous period that followed 1917. State repression surely dealt its blows to the organizational apparatus, but the IWW contained too great of built-in weaknesses to overcome those blows. If the organization were to survive, Gambs argues, it would have to become more flexible, adaptive and eager to renew its forces to meet the challenges of the day.

In 1973, Leland Robinson carried out the first comprehensive analysis of the decline of the movement since Gambs, using his dissertation on the IWW as a case study of social movements in decline, a prelude to several other works on international social, political, and religious sociology. In contrast to the other historians, Robinson reflects "New Age" humanist thinking regarding conflict resolution and interpersonal relations within communities, an emphasis that re-emerged as he later pursued Eastern religious studies. Robinson aligns himself with an organizational approach to the decline of social movements, by which historians uncover how groups respond internally to the inevitable changes that take place in society. $\mathrm{He}$

${ }^{46}$ Ibid., 206. 
claimed that such a perspective was missing from political and social movement history. The main issues he explores are financial problems after $1924,{ }^{47}$ aggravated by a hostility to fundraising and "capitalist" business affairs such as advertising. ${ }^{48}$ These liabilities, he contends, resulted in "pressures tending to cause them to neglect and forsake their goals," compounded by internal divisions that made it impossible to wage a genuine defense of the organization. ${ }^{49}$

Coming from a background of sociology rather than social history, Robinson examines the movement as a network of individuals and groups that operated within binary tensions of a subjective character, such as change versus stability, or "pure" versus mainstream ideologies. "The mere fact that a movement organization is in decline does not relegate it to a fixed pattern of transformation," Robinson writes. "The dynamics of movement organizations may be seen as the result of the continuous interaction of various pressures for change and pressures for stability." ${ }^{50}$ Rather than portraying the decline as a thread of practical-strategic errors sparked by external pressures, as Gambs and Dubofsky had, Robinson sees these failures through a humanistic light where individual actors worked under general goals that were simply too difficult to achieve:

The pressures and counter-pressures can all be traced to 'people doing things together.' They are the results of such things as the members of declining and declined movement organizations trying to solve concrete problems of maintaining their organization, trying to work toward goals which they hold in common, trying to realize what they regard as organizational values, trying to deal with the effects of competing organizations and ideologies, trying to deal with the opinions of what are considered relevant groups of

\footnotetext{
${ }^{47}$ Robinson, Social Movement Organizations in Decline, 91-92.

${ }^{48}$ lbid., 293-97.

49 Ibid., 297.

${ }^{50}$ Ibid., 272.
} 
non-members, trying to maintain member enthusiasm and commitment, reacting to the changing composition of the organization's membership and so forth. ${ }^{51}$

Nevertheless, there seems to be a disconnect between the immense amount of historical content contained in Robinson's dissertation and the value of the conclusions offered, given their implications. Was it plausible to suggest that the IWW's issues were rooted in the failure to achieve interpersonal unity? What could they have done differently? Should the Wobblies have attracted "better" individuals? Or engaged in interpersonal conflict resolution training? The demand to produce a cohesive organization in which everyone got along seems more a suggestion in hindsight from the New Age activism of Robinson than an assessment of an organization existing in a different historical period with different cultural and political lenses. Further, the suggestion does little to connect the internal issues with the external context that gave rise to the issues in the first place, connections which are strongly presented in the other works.

Melvyn Dubofsky is among the leading historians of the IWW, author of the authoritative text, We Shall Be All. As a long-time professor at Binghamton University, SUNY, Dubofsky studies U.S. labor and twentieth century history from a perspective generally favoring political and organizational efforts of the working class. He has written the biographies of former president of the United Mine Workers of America John L. Lewis and "Big Bill" Haywood of the Wobblies, as well as other labor-related histories. ${ }^{52}$ Dubofsky approaches the decline of the IWW with a sympathetic intrigue, but does not accept the ultimate cause of decline to be state repression. He disagrees with the arguments that make fundamental the element of state

\footnotetext{
${ }^{51}$ lbid., 273-74.

52 Dubofsky's works include John L. Lewis: A Biography (University of Illinois Press, 1986); Big Bill Haywood (St. Martin's Press, 1987); The State \& Labor in Modern America (Chapel Hill: University of North Carolina Press, 1994); Labor in America: A History (England: Wiley-Blackwell, 2017). Referenced in biography in Dubofsky, We Shall Be All, 299.
} 
repression, which incorrectly emphasize "external repression" above "internal inadequacies." ${ }^{23}$ In his analysis, he critiques the internal response of the movement to all types of issues, whether they be strictly organizational, or arising from state repression and programmatic disagreements.

In terms of the strictly organizational, Dubofsky emphasizes the impact of the "leadership drain" that was "simply too great a handicap for an organization as inherently weak as the IWW" that "few organizations could have survived." ${ }^{4}$ In the lead-up to the 1924 convention that officially split the movement, the union found itself without any of the firm and experienced "old guard", leading it to prioritize improvements for its members over revolutionary commitments. ${ }^{55}$ The abandonment of revolutionary commitments weakened the organization by eroding the foundations that offered cohesion for members of diverse views, as well as the militancy that distinguished the IWW from other unions. In the process of being uprooted from their common program and unconsciously immersed in day-to-day tasks, serious problems came to the fore. Leaders tended to neglect crucial needs like finances, including the iconic Haywood when he was released from prison. While legal defense campaigns to save "class war prisoners" preoccupied much of the leadership's time, they mostly failed to combat the hardlined repression by the U.S. government. Torn over how to wage a defense of their members while keeping their principles, the presidential offers in 1922 and 1923 exacerbated the strategic fissure emerging from within. When President Coolidge commuted the sentences of all remaining wartime prisoners in December 1923, an organization-wide distrust of released members arose due to their alleged betrayal of defending the movement's legality.

\footnotetext{
${ }^{53}$ Dubofsky, We Shall Be All, 269.

${ }^{54}$ Ibid., 260-61.

${ }^{55}$ Ibid., 260.
} 
Without strong leadership or cohesion, the union did not hold national conventions as often and left the administrative side of the organization in chaos. Dubofsky suggests that, due to these deficiencies in the midst of a repressive crackdown, the organization struggled with the following key issues: "The status of its political prisoners, its relationship with the Communist party at home and the Comintern abroad, and the distribution of power within the organization between centralists and decentralists, industrial unionists and anarchists." 56 These issues, although highly political, are addressed more from a tactical standpoint. Contrary to historians who place primacy on the political questions over the organizational features, Dubofsky emphasizes that "disagreements over communism [for example] further aggravated the IWW's internal disorders," listing a series of interpersonal reflections of the broader political and strategic divisions. ${ }^{57}$

On the question of union relations, Dubofsky stresses the isolation that the IWW had dug itself into by embarking on a road independent of post-war changes that brought a new wave of union and political affiliations. Company-tied unionism became more mainstream due to the ability of American corporations, with the help of the government and weakening AFL, to meet the basic demands of workers for higher wages, eight-hour work days, and better conditions, a general pattern that varied by industry. Dubofsky pointed out several examples to clarify the differences across occupations and regions. Often times, the whole structure of industries changed, as in agricultural occupations, where the demand for labor decreased with the mass introduction of the combine, while simultaneously the migratory harvesters that were once a pillar of the IWW turned more into family men that "travelled as far and as often as their battered secondhand cars carried them." ${ }^{58}$ In these cases, the IWW had difficulty keeping up with

\footnotetext{
${ }^{56} \mathrm{lbid}$.

${ }^{57}$ Ibid., 264.

58 Ibid., 256.
} 
structural changes. Other industries remained relatively similar to the wartime period, like those based on waterfronts and ports, yet still the IWW fell into isolation. In one example that highlights the movement's challenges, the Marine Transport Workers' Industrial Union in Philadelphia, founded as an IWW organization in 1913, decided to switch affiliations to the AFL after the Wobblies' national leadership challenged their ability to set local dues higher than constitutional limits. Dubofsky argues that these feuds arose from pressure to strengthen the movement's position as a labor group in the midst of competition, a task which could not be achieved without overcoming its weak points.

Internal debates turned into feuds, with none of the existing leaders willing or capable to carry out the necessary organizational changes that could have helped them retain high membership numbers. Leaders failed to initiate necessary measures at a time when decisions regarding strategy and perspective were critical to the IWW's positioning within working class struggles. However, Dubofsky writes, "given the internal deficiencies of the IWW, the aspirations of most of its members during the organization's heyday, and the dynamics of American capitalism, the Wobblies' attempt to transform American workers into a revolutionary vanguard was doomed to failure." ${ }^{59}$ Even during the IWW's best three years during World War One, he contends it faced trouble maintaining union benefits as labor-management relations changed, lost all its best leaders from repression, pursued mostly-failed defense campaigns, endured intense conflict over strategy and policy, and thereby failed to meet the challenges of the Bolshevik Revolution and state repression. "It is remarkable that the organization survived at all," he concludes, claiming that the combination of these issues would have broken most other organizations. ${ }^{60}$

\footnotetext{
59 Ibid., 269.

${ }^{60}$ Ibid., 258.
} 
Dubofsky suggests that in order to retain their influence as a labor movement, given that becoming a communist or anarchist movement was not an option after 1922, they would have had to do "what the CIO did." ${ }^{\text {C1 }}$ This means establishing more official industrial unions, accepting more long-term and bureaucratic positions, and engaging in collective bargaining. However, he begs the question, if these changes had been implemented and the organization survived well into the radical mainstream of the 1920 s and 30s, "what would have remained of its original purpose?"62 Thus, Dubofsky offers a pessimistic approach to the decline of the IWW, seeing the original project as one that could only thrive in a prior period and lacked the qualities to change the movement in alignment with the organizational and programmatic needs of workers during the 1920s.

\section{Perspectives on Political Strategy and Program}

The majority of scholarship and writing in the field regard state repression as a brutal pressure which exacerbated the movement's many issues, related to either internal organization or political and programmatic perspective. The latter group consists of a handful of authors, mostly modern historians, ${ }^{63}$ who focused on the divide within the IWW arising from tensions between conservative unionism, industrial syndicalism, and radical politics like communism and anarchism that emerged with more strength after the Russian Revolution in October 1917.

Interestingly, the first figure who shared this perspective wrote decades before the other two historians. James P. Cannon was a former Wobbly who fled in the post-1917 crisis for communism and later led the American Trotskyist movement for decades after 1928. Cannon wrote an essay for the Fourth International magazine (1955) on the topic of the IWW collapse

\footnotetext{
61 lbid. 271.

62 Ibid.

${ }^{63}$ Kenyon Zimmer, "Premature anti-communists?" 45-71; Robert Goldberg, "One Big Union," 41-65.
} 
for the purpose of educating members of his party, the Socialist Workers Party (SWP), as well as workers with which they were regularly engaged. ${ }^{64}$ As someone who had acquired a more concrete political orientation since he left the Wobblies, Cannon aimed to explain his former movement's collapse as a product of unresolved political issues arising from the Bolshevik Revolution and First World War. These major world events, he argued, were at the heart of the infamous 1924 split in the IWW, despite the various immediate concerns which dominated the tense atmosphere during the convention. It was during this convention that the caps burst off all simmering conflicts, regarding the heavy state suppression it experienced and the future path for the struggling organization.

Coming from a Marxist theoretical background, Cannon rejects the common obsession over key figures and internal conflicts, instead placing greater emphasis on the objective dynamics of world politics, competing class interests, and how these impact revolutionary movements. Thus, like the other authors, he agrees that the IWW was pushed to the fringes, perhaps because of an inherent weakness within anarchist politics (or its lack of politics to be more precise), relative to other leftist tendencies. With the majority of the Wobbly leadership denouncing the "workers' state" after initial support, the organization ceded influence to the Communist Party, Cannon wrote, and was not strong enough to endure the isolation, repression and splits which it experienced. Contrary to the fixed mindsets of the majority of the IWW, the defense campaign would not save the organization from repression and collapse, but rather the development of political perspectives on major questions a revolutionary organization must comprehend, such as the nature of the Soviet Union, class struggle, socialism and communism. While leading members initially attempted to study these issues and develop the program of the IWW according to their implications, among them Haywood and Cannon, the bulk of the "old

\footnotetext{
${ }^{64}$ Cannon, The I.W.W.
} 
guard" did not change their anti-political ways and rejected the struggle for workers' state power. "The big majority, after several years of wavering, went the other way [from support for the Russian Revolution]. That sealed the doom of the IWW, " Cannon asserts. "Its tragic failure to look, listen and learn from the two great events condemned it to defeat and decay."65

Even with this sharp critique of the organization's decisions, Cannon does not hold bitter resentment toward the syndicalist and anarchist perspectives, nor does he assign a fatalistic character to the movement's eventual collapse. In fact, the Trotskyist leader deemed the IWW the "most militant, the most revolutionary section of the workers' vanguard in this country," and one that was “much nearer to Lenin's conception of a party of professional revolutionists than any other organization calling itself a party at that time." ${ }^{\prime 6}$ Thus, to Cannon, the collapse of the IWW was a "historical miscarriage which might have been prevented" if there had been a stronger Communist leadership, deeper discussions on the issues within the membership, and a concerted effort to win over leaders. Although this recommendation to develop a more firm strategy is shared by all of scholars who focus on the political issues, Cannon is the only one who advocates a Communist trajectory. The essay also stands out as one of the only non-academic pieces, allowing a more open disclosure of political leanings. The author does not hide that he operated within the Communist movement after the decisive split from the IWW, nor that he used the essay for the purpose of educating his party and workers coming into the movement in the Cold War period of the 1950s.

Writing over half a century after the Wobbly-turned-Trotskyist, Kenyon Zimmer (2009) also accounts for the impacts of the Bolshevik Revolution on the development of the American anarchist movement, of which the IWW was an overlapping part. However, he takes an approach that is much more sympathetic to anarchism, while hostile to socialism and

\footnotetext{
${ }^{65}$ Ibid., "The Turning Point."

${ }^{66} \mathrm{lbid}$.
} 
communism. Zimmer is an Associate Professor of History at the University of Texas, Arlington with research interests in the history of anarchism, syndicalism and immigration. As a modern labor historian, he draws upon an immense amount of history pertaining to anti-communism in the United States, contributing to perspectives which regained popularity after the dissolution of the Soviet Union in 1991.

While the Industrial Workers of the World was not a fundamentally anarchist organization, its cross of industrial unionism and revolutionary syndicalism attracted many anarchist supporters. Anarchism had deep ties to the IWW on an organizational and political level, especially in the heat of the Russian events in 1917. "American anarchism entered into an irresolvable crisis after 1917," writes Zimmer, with their lodging of antagonisms against both American capitalism and the Soviet state, which were viewed as repressive. This left the movement "increasingly marginalized and ineffectual." ${ }^{67}$ Although sympathetic to anarchism, Zimmer places ultimate blame for the collapse on the movement's failure to develop an effective program independent of both capitalism and communism. He supports this point with a fairly comprehensive analysis of the roots of the anti-communism within the IWW.

According to Zimmer, the relationship of anarchism and Bolshevism was generally positive in the immediate aftermath of the Bolshevik Revolution. Russian-American anarchists were allowed to return to their home country when the Soviets gained control, and thousands took advantage of the opportunity. Emma Goldman, one of the more famous Russian-American anarchists who returned from a visit, reported that they "left this country with the determination to help the Bolsheviki." Fellow anarchist Alexander Berkman praised the Bolsheviks as "the expression of the most fundamental longing of the human soul that demands fullest individual liberty." ${ }^{8}$ In fact, many non-Russian American anarchists attempted to join the Red Guard

\footnotetext{
${ }^{67}$ Zimmer, "Premature anti-communists?" 44.

${ }^{68}$ Ibid., 50.
} 
workers' army, though their goals were hampered by the U.S. government's ban on travel to the Soviet Union.

However, as the Civil War intensified within Russia, with the Bolshevik Red Army fighting off the White Army between 1918 and 1922, anarchists were not granted the political autonomy they had initially anticipated when their anti-Bolshevik and anti-statist expressions were shut down by Soviet authorities. From 1917 through the early 1920s, anarchists in the United States disagreed on how to approach the Soviet Union. In the socialist state they saw, on the one hand, a successful revolutionary road, and on the other, a potential dead-end of state repression that parallelled capitalism. "Amid this confusion, repression, and lack of information, wishful thinking contributed much to initial anarchist impressions of Bolshevism," writes Zimmer. ${ }^{69}$ Emma Goldman released My Disillusionment in Russia in 1923, a reflection on the repression faced by anarchists in the Soviet Union, which had a marked impact on the anarchist and other anti-Bolshevik layers within the IWW in the lead up to the 1924 split. $^{70}$ The confusion finally hit a turning point when ACLU founder Roger Baldwin and other liberals published Letters from Russian Prisons in 1925, detailing the conditions that anti-Bolshevik political figures faced during the period of "War Communism", notably just one year after the 1924 IWW convention.

Zimmer notes the direct conflict within the IWW over the question of communist politics. The newly-founded Communist International made a concerted effort to bring the IWW into the international movement, especially through sympathetic Wobbly Harrison George.$^{71}$ Though the first referendum to join the Comintern was rejected by IWW representatives in 1918, the General Executive Board made several gestures in support of the Bolshevik state. It removed

\footnotetext{
${ }^{69}$ Ibid., 51.

${ }^{70}$ For her original work, see Emma Goldman, My disillusionment in Russia (New York: Doubleday, Page \& Co, 1923); For its impact on the IWW, see Marian J. Morton, Emma Goldman and the American Left (1992), 106-109.

${ }^{71}$ See speech in George, The Red Dawn.
} 
the anarcho-syndicalist editor of its One Big Union Monthly for criticizing the Bolsheviks, suspended Philadelphia's Marine Transport Workers Local 8 for loading munitions that Communist sources alleged were to be used against the Red Army, and accepted an invitation to the founding convention of the Communist Red International of Labor Unions (RILU) in Moscow in 1919."72 Many members also retained pro-Bolshevik leanings following the IWW convention in 1924 , roughly 2,000 Wobblies affiliated with one of the parties in the American communist movement. Eventually, writes Zimmer, "neither the Communists nor the anarchists had carried the IWW, which was itself decimated in the contest."73 $\mathrm{He}$ attributes the IWW's indecisive path to its "fear of exacerbating its internal divisions, reluctance to explicitly link itself to anarchism, and its own ambitions of becoming an international labor body."74

Zimmer repeats Cannon's arguments about politics as fundamental to the IWW split and collapse, but from the opposite position. In other words, the anarchist criticisms of the Soviets within the IWW were justified and nuanced, but their indecision in moving into one of the fixed anti-Bolshevik camps--conservative trade unionism or anarchism--became their fatal error. Also, while Zimmer takes the position that U.S. state repression placed significant pressures on the IWW, he expands that position to include repression by communists. Zimmer's perspective on the IWW's failure to attach itself to a coherent political banner, therefore, places the situation within the context created by both the October Revolution and the triumph of American capitalism.

Finally, Robert Goldberg provides a concise overview of the IWW's early history and especially its decline as a relatively modern professional historian with a broad interest in social movement history. Due to this background, he offers an abbreviated perspective on the political

\footnotetext{
${ }^{72}$ Zimmer, "Premature anti-communists?" 57.

${ }^{73}$ Ibid., 61.

${ }^{74}$ Ibid., 59.
} 
roots of the IWW's decline as one chapter in his larger book Grassroots Resistance: Social Movements in Twentieth Century America, which examines a range of organizations and movements as ideologically diverse as the Ku Klux Klan and Student Nonviolent Coordinating Committee. In the chapter "One Big Union: The Industrial Workers of the World", Goldberg outlines perspectives that overlap heavily with Zimmer, but without the same openly pro-anarchist positions. Like Zimmer and Cannon, he emphasizes the tension that communism posed to the industrial syndicalist organization, concluding with a drastic 10 to 20 percent of Wobblies joining the Communist Party after the 1924 convention. Wobblies "scorned [Communist] members as politicians and cited their opposition to armed insurrection and the seizure of power by force," writes Goldberg. "They also denounced the foreign control of the movement, its stress on bureaucracy, and an authoritarianism that subjugated individualism to the party line."75 The opportunist maneuvers and anti-communist position of the IWW majority pushed it out of the mainstream of radical politics for the remainder of its life. When faced with state repression and inexperienced leadership, a coherent political perspective that united its strongest remaining leaders, expanded its base of support within broader layers of the working class, and guided conscious and organized activity in the midst of drastic historical changes was essential. However, this did not occur.

Zimmer and Goldberg essentially put forward the same argument, that the anarchist and syndicalist base of the IWW generated a hostility to communism while the communist movement gained a huge following after the October Revolution. This fueled sharp internal conflicts over the direction of the movement and shifted its external relations from mass politics to fringe radicalism. While Cannon also examines the split between anarchism and communism, he does so with a greater emphasis on class struggle, revolution, state power, and the lessons of the

\footnotetext{
${ }^{75}$ Goldberg, "One Big Union,” 63.
} 
Russian Revolution. He identifies communism as the emerging "radical mainstream" in American politics, and in fact world politics, pushing the anarchistic and anti-communist elements within the IWW onto the fringes. While he does not have nearly the same level of historical background on the roots of anti-communist sentiments within the IWW as Zimmer, they share the same approach only with opposed conclusions specific to their respective political sympathies.

\section{Conclusion: Toward a Critical and Comprehensive Narrative}

By assimilating new material and revisiting prior work, each author contributed to the historical understanding of why the Industrial Workers of the World declined after 1917. I have reviewed notable works that represent the major arguments within the broader body of literature, though many more scholarly articles, books, movies and even music on the subject exist beyond the scope of my project. In bringing these histories into communication with one another and suggesting their potential origins, certain implications have emerged regarding the challenges and potential successes for unions and social movements.

The narratives that emphasize state repression offer the most fatalistic of conclusions. Whatever internal features the Wobblies could consciously affect, these authors argue that the counterrevolutionary forces of the state, corporate interests, and the conservative elements of the middle class held the power to crush whatever organization they choose. One must ask these authors, what could be said of organizations that did survive state repression, in the United States and internationally? Further, if the state always wins, what is the purpose of building left-wing social and labor movements in the first place? Given that these authors exclusively wrote these narratives during or after the right-wing turn in mainstream politics in the 1970s, their pessimistic view of radical social movements surviving repression is 
understandable. However, the scholars of this "pessimistic minority" conducted their work after prior historians argued the opposite by exploring in detail how the Wobblies may have responded poorly to external conditions. The work of this minority is valuable in what information they offer the historical community, but its implications are limited, especially for a new generation of workers and political activists who may desire advice on how best to handle the internal and programmatic conditions of their own movements.

Although rooted in an understanding that state repression and cultural backlash contributed to the difficult conditions in which the IWW operated, the historical works that emphasize internal organizational weaknesses and programmatic strategy offer more compelling arguments that often intersect with each other. Authors who stress internal weaknesses express strong criticism of the IWW, but have published some of the most comprehensive and highly-regarded analyses of the organization's life and death, focusing on the reactions of its members and leaders to the conditions imposed upon it. While never taking a fatalistic approach, these scholars often argue that the weakened membership and decentralized structure of the Wobblies made their collapse inevitable. I refer to this group as the "pessimistic majority," since they consist of influential scholars who label the major transformation necessary for the IWW's survival a near-impossible project. Further, while the union could have taken steps to drastically change and improve itself in order to meet the challenges of a changing world, one can only speculate as to the outcomes of potential solutions. As Melvyn Dubofsky poses, the Wobblies would have had to revoke many of their foundational anarchistic and syndicalist tenets if they were to pursue more centralized organization, standard trade unionism, or political engagement, meaning they wouldn't remain Wobblies at all. 
Similarly, the authors who stress political and programmatic questions recognize that the Wobblies had to turn to a more defined strategic camp, as the pressures of the Bolshevik Revolution and post-war changes exacerbated long-standing conflicts and disagreements. Despite the diversity of the authors' political backgrounds--with Cannon suggesting a communist turn, Zimmer and Goldberg suggesting either an anarchist or trade unionist turn--they agree with the fundamental point that the IWW had to figure out what they were fighting for and where they were headed. Again, speculative questions remain, as it is impossible to know whether the IWW would have survived if it turned toward anarchism, communism, or standard trade unionism. Additionally, by restricting their movement to a well-defined program, they likely would have been forced to sacrifice the anti-political, pluralistic and pragmatic aspects of their earlier life, qualities that distinguished the IWW from all other unions and social movements. For example, should the Wobblies have embarked upon a more standard industrial unionist road in the 1920s, regaining traction and members, they would have confronted the decision to join the $\mathrm{ClO}$ after 1935, where the IWW would find itself estranged from communist workers and the large-scale actions carried out in whole industries. ${ }^{76}$

While the speculative questions may never be answered, they reveal the strengths of the authors who investigated the response of the IWW in terms of organizational and programmatic issues, in particular the possibility of the Wobblies successfully overcoming repression. What was necessary and lacking at the time was a reorientation of the movement on a path that aligned with their intended goals and the reality of a changing external world. Organizational elements cannot be seen as entirely separate from the political issues, as the factional infighting

\footnotetext{
${ }^{76}$ While Wobbly-style tactics like the sitdown strike were employed by workers of the $\mathrm{CIO}$, the CIO achieved far greater success than the IWW in areas of diversity and direct action, which were applied in mass production industries rather than just extractive industries. Further, the Communist Party occupied roughly one-quarter of officer positions in CIO locals. See Robert Zieger, The CIO, 1935-1955 (University of North Carolina Press, 1995).
} 
and other stressors grew out of or were made more severe by the tensions between programmatic groupings. However, political and programmatic questions seem to be more essential than the organizational problems, since they lay the primary basis for organizational matters to be dealt with. How can financial difficulties, leadership weaknesses and interpersonal difficulties be resolved if the movement does not have a common program that its members democratically support? Thus, I encourage future historical research and mainstream sources on the IWW's decline to embrace a new historical narrative, which takes a critical approach to the exclusive blame on state repression while accounting for the centrality of political and related organizational problems. Such an approach may open the path for critical and comprehensive analyses of the IWW, as well as social movements in general.

\section{Works Cited}

AFL-CIO. "Samuel Gompers," Key People in Labor History. (2019) Web.

Bayard, Charles. "The 1927-1928 Colorado Coal Strike," Pacific Historical Review. Vol. 32, No. 3. (1963)

Bird, Stewart.; Georgakas, Dan.; and Shaffer, Deborah. Solidarity Forever: An Oral History of the IWW. (Chicago: Lakeview Press, 1985)

Brissenden, Paul. The IWW: A study of American syndicalism. (Russel \& Russel, 1920)

Bryans, Andrew. "The response to left-wing radicalism in Portland, Oregon (1917-1941)," PDXScholar. Masters in History thesis. (2002) 
Brooks, John Graham. American Syndicalism: The IWW. (New York: The Macmillan Company, 1913)

Cannon, James P. "The I.W.W.," Fourth International. (1955)

Caulfield, Norman. "Wobblies and Mexican Workers in Mining and Petroleum, 1905-1924," International Review of Social History. (1995) 51-75.

Cohen, Lizabeth. Making a New Deal: Industrial Workers in Chicago, 1919-1939. (Cambridge University Press, 1990)

Cole, Peter. Wobblies of the World: A Global History of the IWW. (London: Pluto Press, 2017)

Central Executive Committee of the Communist International. "To the I.W.W., A Special Message from the Communist International" (1920). Retrieved from Marxists Internet Archive.

Dubofsky, Melvyn. We Shall Be All: A History of the Industrial Workers of the World. (University of Illinois Press, 1993)

Ficken, Robert E. "The Wobbly Horrors: Pacific Northwest Lumbermen and the Industrial Workers of the World, 1917-1928," Labor History, Vol. 24 (Summer 1983) 325-41.

Foner, Phillip. "Labor and World War I, 1914-1918," History of the Labor Movement in the United States. Vol. 7. (International Publishers, 1987)

Gambs, John. The Decline of the I.W.W. PhD Dissertation. (Columbia University Press, 1932)

George, Harrison. The Red Dawn: The Bolsheviki and the IWW. (Chicago: I.W.W. Publishing Bureau, 1918)

Goldberg, Robert. "One Big Union: The Industrial Workers of the World," Grassroots Resistance: Socialist Movements in the 20th Century. (1990) 41-65.

Goldman, Emma. My disillusionment in Russia. (New York: Doubleday, Page \& Co, 1923). Reprint, (New York: Thomas Y. Crowell Company, 1970)

Goldstein, Robert J. Political Repression in Modern America: From 1870 to the Present. (Cambridge, 1978) 125-29.

Green, Archie. The Big Red Songbook: 250 IWW Songs! (C.H. Kerr Company, 2016)

Gregory, James and Conor Casey, The IWW History Project (University of Washington, 2019) Web. 
Hall, Greg. Harvest Wobblies: The Industrial Workers of the World and Agricultural Laborers in the American West, 1905-1930. (Oregon State University Press, 2001)

Hamilton, Neil. Rebels and Renegades: A Chronology of Social and Political Dissent in the United States. (Routledge, 2002) 133-198.

Hodges, Adam. "Thinking Globally, Acting Locally. The Portland Soviet and the Emergence of American Communism (1918-1920)," Pacific Northwest Quarterly, Vol. 98, No. 3. (Summer 2007)

----- "The Industrial Workers of the World (IWW)," Oregon Encyclopedia (2018).

Industrial Workers of the World. "The Original I.W.W. Preamble." General Website. (2018)

Kazin, Michael. War Against War: The American Fight for Peace, 1914-1918. (Simon and Schuster, 2017)

Morton, Marian J. Emma Goldman and the American Left: "Nowhere at Home." (New York: Twayne of Macmillan, 1992)

Ottanelli, Fraser. The Communist Party of the United States: From the Depression to WWII. (Rutgers University Press, 1991)

Palmer, Bryan D. James P. Cannon and the Origins of the American Revolutionary Left, 1890-1928. (University of Illinois Press, 2007)

Parfitt, Steven. "The Justice Department Campaign Against the IWW, 1917-1920", The IWW History Project. (University of Washington, 2015)

Robinson, Leland W. "Social Movement Organizations in Decline: A Case Study of the IWW." Ph.D. dissertation. (Northeastern University, 1973)

Ross, Jack. The Socialist Party of America : A Complete History. (Dulles: Potomac Books, 2015) 58-236.

Scheetz, Kathleen. "Industrial Workers of the World," Encyclopedia Britannica. (2019)

Thompson, Fred, and Murfin, Patrick. The IWW., Its First Seventy Years, 1905-1975. (Chicago: Industrial Workers of the World, 1978)

Townsend, John Clendenin. Running the Gauntlet: Cultural Sources of Violence against the IWW. (New York: American Legal and Constitutional History, 1986)

Tyler, Robert L. Rebels of the Woods: The IWW in the Pacific Northwest (Eugene: University of Oregon Books, 1967) 
Wiggins, Teke. "The Food Industry Has Been Notoriously Hard to Organize," Huffington Post. (October 9, 2018)

Winsor, Ryan. "Workers of the World Unite!: The Powell's Books Union Organizing Campaign 1998-2000". PDX Scholar, Masters in History thesis (Portland State University, 2017)

Zieger, Robert. The CIO, 1935-1955. (University of North Carolina Press, 1995)

Zimmer, Kenyon. "Premature anti-communists? American Anarchism, the Russian Revolution, and Left-Wing Libertarian Anti-Communism, 1917-1939." Labor: Studies in Working-Class History of the Americas, Vol. 6, No. 2. (2009) 45-71. 